\title{
Editorial - The Potential of European Public Procurement Regulation
}

The newly appointed European Commission for the forthcoming legislature of the European Union has inherited a wealth of actions from the $8^{\text {th }}$ and $9^{\text {th }}$ legislatures $(2009-2019)$ of the European Parliament which places public procurement at the heart of the internal market and recognises its function as an essential component of the European economic integration.

The main ingredients of the public procurement legacy during the $8^{\text {th }}$ and $9^{\text {th }}$ legislatures (2009-2019) of the European Parliament are the following:

- Public Procurement is an industrial policy component for the EU 2020 Growth Strategy reflecting on strategy, innovation, socio-economic and environmental objectives;

- Technologies and information and communication systems such as E-Certis and ESPD would enhance the efficiency and effectiveness of the regulatory system;

- The modernisation of public administrations in Member States will lead to interoperable procurement systems;

- The digitization agenda which will enhance SME participation and improve cross border procurement;

- The professionalization and commercial awareness of procurers in Member States will improve the quality of decisions leading to the award of public and utilities contracts;

- Contracts below the thresholds which trigger the application of the public procurement rules could pose considerable barriers to market access for cross-border procurement.

In order to strengthen the Single Market and as part of the continuous effort to stimulate investment in the EU and its Member States, a policy initiative has been launched to carry out procurement more efficiently through digital technologies and in a sustainable manner from socio-economic perspective.

The policy package was introduced by the EU Commission on the $3^{\text {rd }}$ of October 2017 where six priority areas have been earmarked for Member States to develop a strategic approach to procurement. The policy initiative on public procurement recognises the importance of soft law to carry the reform agenda of the public procurement acquis. Although EU Member States have benefited from the reform agenda carried by the 2014 Public Procurement Directives, the need for further simplification and addressing successfully barriers to market is essential in influencing the strategic application of the new rules.

Public Procurement is regarded as essential lever for the EU 2020 Growth Strategy. For such lever to impact upon Member States, the modernisation of public administrations is regarded as critical. The introduction of technologies to public procurement, especially information and communication technologies (ICTs) would allow for the efficiency and effectiveness of the regulatory system. Concepts such as end-to end procurement and interoperable procurement are the result of the digitization agenda which will enhance SME participation and improve cross border procurement.

The soft law package of 2017 includes a number of action priorities such as greater uptake of innovative, green and social criteria in awarding public contracts; professionalization of public buyers; improving access by SMEs to procurement markets in the EU and by 
EU companies in third countries; increasing transparency, integrity and quality of procurement data; digitisation of procurement processes; and finally more cooperation among public buyers across the EU.

\section{Strategic Procurement}

Strategic procurement in the EU embraces the pivotal importance of the SMEs in achieving economic growth. Public procurement is of utmost economic significance for European SMEs. Although the Public Procurement regime deals effectively with sub-contracting issues, prompt payments and the promotion of SMEs in the selection and qualification procurement phase and the award of public contracts, SMEs across the EU Members States face barriers to accessing public procurement markets and win public contracts. Apart from inherent differences between countries, the value of public contract is one of the major factors that influence the extent to which SMEs can access public contracts. The larger a contract (ie single awards/lots), the less likely it will be awarded to SMEs. Other factors influencing SMEs' share in winning public contracts are the type of contract, the procurement sector, the award procedure and the award criteria.

SMEs' account for a considerably lower proportion of above-threshold supplies contracts than that of public works contracts; SMEs play only a marginal role in the supply of commodities, but they accounted to more than three quarters of the contract volume in other procurement sectors; The share of contract volume awarded to SMEs is sensitive to tenders awarded by central government, regional and local authorities and agencies and utilities; SMEs take a much smaller share of the total value of contracts awarded under the various negotiated procedures than under open procedure or restricted procedures. SMEs are not likely to win contracts when the competitive dialogue is utilised; and finally, SMEs are not likely to win contracts when the lowest offer is utilised as award criterion.

\section{Innovative Procurement}

Innovation in the delivery of public services is a priority for procurement regulation and will be achieved through the new procedure of innovation partnerships and the new award criterion of life cycle costing. Innovation partnerships is an award procedure designed to improve market pull by combining a research contract with a realistic chance to obtain a first purchase if the research result fulfils pre-defined performance levels. Innovation partnerships are structured in successive phases with intermediate targets and payments and cut-off options.

On the other hand, life-cycle costing is an award criterion which covers partly or totally costs over the life cycle of a product, service or works which are borne by the contracting authority or other users, such as costs relating to acquisition, costs of use, such as consumption of energy and other resources, maintenance costs, end of life costs, such as collection and recycling costs; or costs imputed to environmental externalities linked to the product, service or works during its life cycle, provided their monetary value can be determined and verified; such costs may include the cost of emissions of greenhouse gases and of other pollutant emissions and other climate change mitigation costs.

\section{Responsible Procurement}

Responsible procurement takes into account socio-economic nature of public service delivery through services of general economic interest and incorporates environmental 
protection as a component of public procurement regulation.

\section{Digital Procurement}

Efficient procurement promotes systems such as electronic procurement and electronic invoicing which attempt to reduce bureaucracy and costs and allow for a more streamlined process in the delivery of public services. The European Single Procurement Document (ESPD) has been adopted as a formal statement by an economic operator consisting of a self-declaration as preliminary evidence in replacement of certificates issued by public authorities or third parties that the relevant ground for exclusion does not apply and/or that the relevant selection criterion is fulfilled and the relevant information as required by the contracting authority shall be provided upon request by the contracting authority or in the event of the economic operator being the winning bidder.

\section{Cross-border Procurement}

An indicator of the state of functioning of the public procurement acquis is the crossborder procurement volumes which reveal the import penetration of goods, works and services destined for the public sector but originating from a different Member State. Crossborder procurement covers both dimensional procurement (above thresholds) and sub-dimensional procurement (below threshold or low volume procurement). Cross-border procurement proves the level of integration in the relevant market, which indicates a transaction (public contract award) can take place with parties in different parts of the single market. This also reveal the effect of the quality of national public procurement legislation on selection and qualification, award procedures and the elimination of national bias systems such as language, culture, and preferences.

The European institutions, through the enactment of the Single Market Act, ${ }^{1}$ have identified public procurement reforms as essential components of competitiveness and growth and as indispensable instruments of delivering public services. ${ }^{2}$

The results of public procurement reforms have been registered in a positive manner. The flexibility of the public procurement regulatory regime is reflected in important recent case-law developments, in particular case-law on the definition of contracting authorities, the use of award procedures and award criteria, and the possibility for contracting authorities to use environmental and social considerations as criteria for the award of public contracts. Further, flexibility underpins the relaxation of the competitive tendering regime and the disengagement of the public procurement rules in industries that operate under competitive conditions in the utilities sectors indicate the links between procurement regulation and anti-trust. The non-applicability of the regime to telecommunications entities is an important development indicative of the future legal and regulatory blueprints.

The recent reforms of the public procurement regime are felt in public-public partnerships and in-house contractual relations between contracting authorities or undertakings upon which the former exercise control similar to that exercised over their own departments and the controlled entities are operationally dependent on them link conceptually

1 Communication to the European Parliament, the Council, the Economic and Social Committee and the Committee of the Regions, Towards a Single Market Act, COM(2010) 608 final.

2 Guide to the application of the European Union rules on state aid, public procurement and the internal market to services of general economic interest, and in particular to social services of general interest, SEC(2010) 1545 final. See Commission, Buying Social: A Guide to Taking Account of Social Considerations in Public Procurement, SEC(2010) 1258, final. 
very well with public contracts awarded by utilities to their affiliated undertakings and public service contracts relating to services of general economic interest and contracts having the character of a revenue-producing monopoly, and as such reflect on the positive dimension of inherent flexibility in the 2014 public procurement Directives.

Public contracts, which fall below the stipulated value thresholds (sub-dimensional contracts), represent the most difficult category for reform and the biggest opportunity for discretionary exercises in public purchasing. On the one hand, they encapsulate a significant amount of Member States' public expenditure, which escapes the clutches of the public procurement acquis. On the other hand, there is an imperative to subject these contracts to some form of competition and has supplemented the public procurement Directives with EU law principles which ensure a parallel process of procurement with dimensional public contracts. This development has created uncertainty in the market place and resulted in a dysfunctional application of procurement rules to those contracts. The administrative and procedural burdens on the part of contracting authorities often surpass any potential efficiency benefits resulting from competitively tendering sub-dimensional contracts. In addition, adequately sufficient safeguards against intentional division of dimensional contracts into lots in order to avoid the applicability of the public procurement Directives exist in the current acquis.

All Public Procurement Directives benefit from the principles of discretion and flexibility in their application by Member States. Discretion of Member States in applying public procurement law is surrogate to the principle of proportionality. The conceptual link is the principle of flexibility in public procurement law which has been developed and deployed by the jurisprudence of the CJEU. The discretion is reflected on the fact that the EU public procurement is enacted and implemented in domestic legal systems by reference to harmonisation, but procurement rules are inherently flexible to accommodate compliance and legal interoperability with EU principles and policies. The doctrine of flexibility allows the principle of proportionality to be employed in the application of public procurement rules by national legal systems.

Further legal reforms are needed and will be implemented in the 2019-2024 session of the European Parliament. The public procurement rules and mainly the public sector Directive suffer from legal porosity as a result of non-exhaustive harmonisation. Non-Exhaustive harmonisation represents a de lege lata approach to public procurement regulation on the part of the European legislature. Such approach has developed certain deficiencies. The effectiveness of the procurement rules is compromised and the CJEU has applied, through a rule of reason approach, a hybrid transplant of EU legal principles to the public procurement Directives in order to control their porosity. However, this treatment is temporary and not conducive to legal certainty and legitimate expectation. 